\title{
Fallopian Tube Serous Adenofibroma
}

National Cancer Institute

\section{Source}

National Cancer Institute. Fallopian Tube Serous Adenofibroma. NCI Thesaurus. Code C40113.

A rare, benign, asymptomatic neoplasm that arises from the fallopian tube. The majority of cases are incidental findings during operation for an unrelated gynecologic disorder. The tumors are round and solitary and contain connective tissue and papillary or tubular structures lined by serous-type epithelium. 